\title{
Impact of an Educational Program on knowledge and Practice of Patients with Chronic Obstructive Pulmonary Disease
}

\author{
Prof. Dr. Magda Abdel-Aziz Mohammed, Prof. Dr. Mamdouh Mohammad \\ Almezaien, Prof. Dr. Raed El-metwaly Ali Eid, Dr. Dina El-tabey Sobeh and Amora \\ Omar Ibrahim El-Mowafy.
}

Professor of Medical-Surgical Nursing, Faculty of Nursing, Ain Shams University,

Professor of Surgery and Vascular, Faculty of Medicine, Suez Canal University, Professor of Chest Medicine, Faculty of Medicine, Mansoura University, Lecturer of Medical-Surgical Nursing, Faculty of Nursing, Port Said University, Master degree in Medical-Surgical Nursing, Faculty of Nursing-Port Said University.

\begin{abstract}
Background: Worldwide, chronic obstructive pulmonary disease (COPD) is in the spotlight because of its morbidity, mortality and high prevalence. In Egypt is highlighted as a major public health problem. The aim of the present study was to evaluate the impact of an educational program on knowledge, practice, and self-efficacy of patients with stable chronic obstructive pulmonary disease. Quasi- experimental research design was utilized in this study. The sample was consisted of all available patients with stable COPD during the time of data collection. Four tools were used to collect data: first; Structured interview questionnaire which consisted of sociodemographic characteristics, and medical history. Second; the Bristol COPD Knowledge Questionnaire (BCKQ), third; Observational checklist which consisted of breathing exercises\& inhaler use, and fourth; Self-Efficacy Scale for Patients with COPD. The result of the study concluded that there was a highly statistically significant difference in patients' total knowledge and practice pre and post program \& pre and follow up program. Concerning total Self Efficacy there was no statistically significant difference between pre and post $\&$ pre and follow up scores, but there was a highly statistically significant difference between pre and post program regarding all self-efficacy issues except with weather /environment, while there was no statistically significant difference between pre and follow up program in all self-efficacy issues except in negative affect issues. The study concluded that after implementation of the educational program, remarkable improvements were occurred in knowledge, practice, and self-efficacy sub scores. The study recommended Continuous monitoring and evaluation of self-efficacy for patients to enhance disease management through establishing a rehabilitation program for patient to improve their self-efficacy. Promotion and enhancement of the self-care modalities to the patient; a strict written instruction with pictures about disease process, allowed foods, rest and physical activities and follow up should be continued after termination of educational program.
\end{abstract}

Key word: COPD, knowledge, Practice, Self-Efficacy, educational program. 


\section{INTRODUCTION}

Chronic obstructive pulmonary disease (COPD) is a leading cause of death worldwide. In addition to generating high healthcare costs, COPD imposes a significant burden in terms of disability and impaired quality of life. Unlike many leading causes of death and disability, COPD is projected to increase in much of the world as smoking frequencies rise and the population ages (Lomborg, 2013).

Chronic obstructive pulmonary disease is a lung disease characterized by chronic obstruction of lung airflow that interferes with normal breathing and is not fully reversible. The more familiar terms 'chronic bronchitis' and 'emphysema' are no longer used, but are now included within the COPD diagnosis. It is not simply a "smoker's cough" but an under-diagnosed, life-threatening lung disease (World Health Organization, 2016).

Smoking is by far the most common risk factor for development of COPD, but other factors such as outdoor, occupational, and indoor air pollution may also cause COPD in the absence of smoking. Factors such as genetics, infections, nutrition, and oxidative stress may also have a role in the development and/or progression of COPD (Walia, Vellakkal, \& Gupta, 2016).

The chronic airway limitation characteristic of COPD is due to inflammation that results in obstruction of the small airways and destruction of lung parenchyma. Common symptoms include chronic cough, sputum production, and progressive, persistent dyspnea that worsens with exertion (Spencer \& Hanania, 2013).

spirometry is now required to make a confident diagnosis of COPD, whereas previously it was used to support the diagnosis. The fixed ratio of post bronchodilator forced expiratory volume in one second $\left(\mathrm{FEV}_{1}\right)$ to the forced vital capacity (FVC), or $\mathrm{FEV}_{1} / \mathrm{FVC}$, needs to be $<70 \%$ and the staging system of spirometry classification, which has now been replaced with grading, uses: $\mathrm{FEV}_{1} \geq 80 \%$ predicted (GOLD 1, mild); $50 \% \leq \mathrm{FEV}_{1}<80 \%$ predicted (GOLD 2, moderate); 30\% $\leq \mathrm{FEV}_{1}<50 \%$ predicted (GOLD 3, severe); and $\mathrm{FEV}_{1}<30 \%$ predicted (GOLD 4, very severe) (Global Initiative for Chronic Obstructive Lung Disease, 2016).

Chronic obstructive pulmonary disease can be prevented and treated, but the disease is incurable and the airway limitation is not fully reversible. As COPD 
progresses, patients are forced to limit their activities and may experience depression and a decline in their quality of life. Patients with COPD also commonly experience comorbid conditions related to aging and/or smoking, including cardiovascular disease, osteoporosis, and depression (Decramer, Janssens, \& Miravitlles, 2012).

One of the most important initial steps for management of COPD is to reduce exposure to risk factors, including cigarette smoke and/or occupational dusts, fumes, and gases. Given the leading role of smoking as a cause of COPD, it may not be surprising that smoking cessation is the only intervention shown to reduce the rate of disease progression and related mortality. Patient education is a particularly important component of smoking cessation intervention, and education about some aspects of COPD may help patients to cope (Thabane \& COPD Working Group 2012).

Pharmacological therapies are useful to manage symptoms, and some are indicated to reduce exacerbations, which become increasingly important goals as the disease progresses. Various classes of drugs may be appropriate based on the patient's symptoms, risk of exacerbation, and grade of airflow limitation .In general, short-acting bronchodilators are recommended as needed at all stages of the disease, and long-acting bronchodilators may be appropriate as regular maintenance therapy for patients with moderate to severe COPD. The long-acting anticholinergic, tiotropium, was also recently approved for reduction of exacerbations in patients with COPD (Karner, \& Cates, 2012).

An inhaled corticosteroid (ICS) may be appropriate as add-on therapy to longacting bronchodilators in patients with severe and very severe COPD. For instance, a combination of the long-acting $\beta$-adrenergic, salmeterol, and fluticasone, an ICS, is indicated to reduce exacerbations in patients with COPD with a history of exacerbations. Systemic corticosteroids are recommended in the treatment of acute exacerbations of COPD, but their long-term use is not recommended due to lack of evidence of benefit and side effect (Chinet, Dumoulin, Honore, Braun, Couderc, Febvre, Mangiapan, Maurer, Serrier, Soyez \& Jebrak, 2016).

As the prevalence of COPD continues to grow, management of the disease still faces considerable challenges. Despite the existence of effective pharmacological treatments, patient adherence is often poor. Side effects of medications and patients' concerns about potential side effects may contribute to poor adherence. Situated as they 
are at the frontline of patient care in the clinic, nurse practitioners play an important role in the management of COPD. Patient understanding of the therapy and selfmanagement have been identified as key outcome indicators. A focus on these indicators will improve nurse care for COPD patients (Lodewijckx, Sermeus, Panella, Deneckere, Leigheb, Troosters, Boto, Mendes, Decramer \&Vanhaecht, 2013).

COPD education was defined as a program which transfers information about COPD and its treatment in written, verbal, visual, or audio forms. Minimal education included the provision of written material alone or a short structured verbal interaction between a healthcare provider and a patient. However, it had to be embedded in a formal program where the primary goal was to improve the knowledge and understanding of COPD. The educational program might be directed towards smoking cessation, improving exercise, nutrition, self-treatment of exacerbations, inhalation technique, or coping with the activities of daily living, or a combination of these (Monninkhof, Van der Valk, Van der Palen, Van Herwaarden,Partridge \& Zielhuis, 2003).

\section{AIM OF THE STUDY:}

\section{This study aimed to:}

Evaluate the impact of an educational program on knowledge and practice of patients with stable chronic obstructive pulmonary disease. This was achieved through:

- Assess knowledge and practice of patients with chronic obstructive pulmonary disease.

- Develop the educational program for patients with chronic obstructive pulmonary disease.

- Implement the educational program for patients with chronic obstructive pulmonary disease.

- Evaluate the impact of implemented educational program for patients with chronic obstructive pulmonary disease immediately and after three months post program.

\section{SUBJECTS AND METHOD:}

The subjects \& methods of this study will be portrayed under the four main designs as follows: 
I. Technical design.

II. Operational design.

III. Administrative design.

IV. Statistical design.

\section{I- Technical design}

The technical design includes; the research design, study setting, subjects, and tools for data collection.

\section{A. Research design:}

A Quasi experimental research design was used in this study.

\section{B. Setting:}

The present study was conducted at outpatient clinic of the respiratory medicine department at Mansoura University Hospital.

\section{Subjects:}

All available patients with stable COPD were included in the study during the time of data collection $(n=120)$

\section{- Inclusion criteria:}

- All adult patients

- Both sexes

- Agree to participate in the study.

\section{- Exclusion criteria:}

- Those with significant co- morbidity (e.g. heart disease, stroke).

\section{D.Tools for data collection:}

Three tools were used to collect data:

\section{Tool I: A structured interview sheet:}

It was developed by the researcher, based on recent and relevant literatures (Mohamed, 2005).

It was consisted of two parts:

- Part 1: socio--demographic Data: which included demographic characteristics of the patients and composed of (6) closed ended questions including (age, gender, marital status, occupation, level of education, and residence). 
- Part 2: Medical History: which included series of questions to elicit patient's medical history, it was composed of:

a) Present medical history: It was composed of (6) closed ended questions including (duration of disease, drug compliance, presence of chronic diseases, types of chronic diseases, smoking status, and smoking type).

b) Past medical history: It was composed of (2) closed ended questions including (signs \& symptoms associated with disease and history of hospitalization).

c) Family history of the disease: It was composed of (2) closed ended questions which included (family history of COPD and degree of relativity).

\section{Tool II: The Bristol COPD Knowledge Questionnaire (BCKQ) sheet}

It was adapted (White, Walker, Roberts, Kalisky, \&White, 2006) to assess patients' knowledge regarding COPD. The Bristol COPD Knowledge Questionnaire (BCKQ) had 13 points; these points covered epidemiology and physiology, etiology, common symptoms, breathlessness, phlegm, chest infections, exercise, smoking, immunization, inhaled bronchodilators, antibiotics, oral steroids and inhaled steroids. each of which contains five statements.". It was translated into simple Arabic language to facilitate data collection from patients then retranslated into English to assure its accuracy.

\section{Scoring System:}

Patients respond to the statements was scored as:

- Incorrect answer $\rightarrow$ (zero)

- Inadequate answer $\rightarrow(1)$

- Correct answer $\rightarrow(2)$

The total score for knowledge was (130), the total score is calculated by summating the number of correct responses (minimum score $=0$; maximum score $=$ 130). The scores can then be converted to percentages. The total score was calculated similar to previous study conducted by (Cosgrove, MacMahon, Bourbeau, Bradley, \& O’Neill, 2013) as follows:

- Satisfactory if the score $\geq 60 \%$ of the maximum score.

- Unsatisfactory if the score $<60 \%$ of the maximum score.

\section{Tool III: Observational checklist:}


It was developed by the researcher based on recent and relevant literatures (Jacob, Rekha, \& Tarachand, 2010). to to assess practices of patients' with COPD which covered the following items:

Breathing exercises including (Pursed lip breathing, diaphragmatic breathing, and deep breathing and coughing exercise).

- Using inhaler (a metered dose inhaler and dry powder inhaler).

\section{Scoring system:}

Practice questionnaire sheet consisted of five procedures;

- Pursed lip breathing consisted of 4 items; total score for each of these procedures was (8).

- Diaphragmatic breathing consisted of (7) items; total score for each of these procedures was (14).

- Deep breathing and coughing exercise consisted of (5) items; total score for each of these procedures was (10).

- A metered dose inhaler consisted of 10 items; total score for each of these procedures was (20).

- Dry powder inhaler, consisted of 9 items, total score for each of these procedures was (18).

Items were scored as following:
- Not done
$\rightarrow(0)$
- Done
$\rightarrow(2)$

The total score for practice was (70), calculated by summating the number of adequately done (minimum score $=0$; maximum score $=70$ ). The scores can then be converted to percentages. The total score was calculated similar to previous study conducted by (Cosgrove, et al, 2013) as follows:

- Satisfactory if the score $\geq 60 \%$ of the maximum score.

- Unsatisfactory if the score $<60 \%$ of the maximum score. 


\section{A proposed educational program:}

This program developed to enrichment of patients with instruction, and knowledge about COPD to promote effective learning and behavioral changes. The COPD educational program in this study consisted of basic respiratory physiology, risk factors, triggers, signs and symptoms and medication, demonstrating the use of inhalers, the use of nebulizer, and promoting deep breathing.

\section{II- Operational design:}

The operational design included preparatory phase, content validity, pilot study, and fieldwork.

\section{a- Preparatory phase:}

It included reviewing of related literature, and theoretical knowledge of various aspects of the study using books, articles, internet periodicals and magazines, as well as pioneer from nursing experts in order to develop the exact tools for data collection and designing the counseling program.

\section{b- Content validity:}

Test validity was conducted to test the tool for appropriateness, comprehensiveness, relevance, correction and clearance through (9) experts, from the Medical-Surgical Nursing staff at the Faculties of Nursing (Port Said, Mansoura and Benha University) and Medical Staff of chest Medicine, Faculty of Medicine, Mansoura University. Experts were from different academic categories (professors and assistant professors). Their opinions were elicited regarding the tool format, layout, consistency, and scoring system.

Testing reliability of proposed tool was done by Cronbach's alpha test (.892).

\section{c- Pilot study:}

A pilot study carried out on $10 \%$ of the sample to test applicability and clarity of the tools. It was conducted before data collection to evaluate the contents and clarity of the questionnaire, reconstruct or modify the questionnaire if necessary, and estimate the time needed to fill in the questionnaire. It was excluded from sample size. 


\section{d- Field work:}

The study was implemented from the beginning of May 2015 to January 2016. The instructional booklet and the educational program were designed based on analysis of the actual educational patients' needs assessment in pretest by using the pre constructed tools. The content of instructional booklet was written in a simple Arabic language and consistent with the related literature based on their level of understanding.

The instructional booklet was consisted of different elements; basic respiratory physiology, risk factors, triggers, signs and symptoms and medication, demonstrating the use of inhalers, the use of nebulizer, and promoting deep breathing and coughing exercise. the data were collected by using these tools as the following:

Tool I: Demographic data and health history sheet.

Tool II: Assessment of patient's knowledge and practice.

Data were collected by the researcher three days per week (Saturday, Monday, and Thursday) during the morning shift by rotation at outpatient clinic of respiratory medicine department of Mansoura University Hospital.

\section{Methods Used:}

Lecture, posters, pictures and group discussion methods.

\section{The study consists of seven sessions:}

\section{- Pre-intervention phase:}

- The $1^{\text {st }}$ session included interviewing the patients to collect data regarding demographic characteristics, past history, present history, and family history of disease (Time allowed: from 10- 20 minutes for each patient).

- The $2^{\text {nd }}$ session included assessment of patients' knowledge about COPD (Time allowed: from 20- 30 minutes).

- The $3^{\text {rd }}$ session included assessment patients' practice (Time allowed: from 10- 15 minutes).

\section{Intervention phase:}

\section{From $4^{\text {th }}$ to $7^{\text {th }}$ session (the educational program):}

The educational program was presented in theoretical and practical sessions for patients, which aided by using booklets. The theoretical part was conducted through 
lectures and group discussions, while the practical part was conducted through redemonstration for breathing procedure. This program consisted of four sessions; each session lasted about 45 minutes and was accompanied by feedbacks. These educational sessions were done either individually or in groups (10-15) patients.

The researcher was contacted with the patients one day weekly for any explanation. Patients were also informed to be in contact with the researcher by telephone for any guidance.

\section{Post-intervention phase:}

The $8^{\text {th }}$ session (post-test): This session included reassessment of patients' knowledge and practice which aimed to evaluate the improvement after applying the educational program by using post - test (immediately and after 3 months from program.) by using the same tools. Questionnaires were filled by the patients under observation of the researcher or by researcher in illiterate patients.

\section{III- Administrative Design:}

An official letter was issued from the Faculty of Nursing, Port-said University to the director of Mansoura University Hospital \& Head of chest department to obtain their permission to conduct the study.

Additional oral consents were taken from the patients who participated in the study after explanation of its purpose. They were given an opportunity to refuse the participation, and they were assured that there information which would be used for research purposes only.

\section{Ethical considerations:}

All ethical issues were taken into consideration during all phases of the study. The ethical research considerations in this study included the following: The research approval was obtained before collecting data, the objectives and the aim of the study were explained to the participants, the researcher maintained on anonymity and confidentiality of subjects, and subjects were allowed to choose to participate or not and they had the right to withdrawal from the study at any time without giving any reason. Values, culture and beliefs would be respected. 


\section{IV-Statistical Design:}

All collected data were organized, categorized, tabulated, entered, and analyzed by using SPSS, (Statistical Package for Social Sciences), software program version 14, which was applied to frequency tables, statistical significance and associations were assessed using the arithmetic mean, standard deviation (SD), chi-square, t-test, Z test, and coefficient correlation (r) to detect the relations between the variables.

- Non-significant (NS)

$$
\mathrm{p}>0.05
$$

- $\quad$ Significant $(\mathrm{S})$

$$
\mathrm{p} \leq 0.05
$$

- Highly significant (HS)

$\mathrm{P}<0.001$

\section{RESULTS:}

Table (1): shows that $89.2 \%$ of the studied patients were in age group of 40-60 years old with Mean $\pm \mathrm{SD}=52.68 \pm 7.17,62.5 \%$ of them were males, $67.5 \%$ were married, and $56.7 \%$ of them were working. As regard to patients' level of education $39.2 \%$ were secondary while $30.0 \%$ were illiterate

Table (2): shows that $43.3 \%$ of the studied patients had COPD for more than five years, and $73.3 \%$ of them were compliant to medication. $77.5 \%$ of the patients had chronic diseases. Regarding smoking status $36.7 \%$ of the studied patients were previous smokers, $17.5 \%$ of them were current smokers and about $43.3 \%$ of them are cigarette smokers.

Table (3): shows that $70.8 \%$ of studied patients had dyspnea and chronic cough. As regard to patients' previous hospitalization during last year, $37.5 \%$ of the patients were hospitalized from 2-4 times, while $7.5 \%$ of them had no previous hospitalization during last year. In relation to family history of COPD; $25.8 \%$ of the patients had family history of COPD and $20.8 \%$ of them had $1^{\text {st }}$ degree relativity.

Table (4): Shows that, there was a highly statistically significant difference between pre and post program in the studied patients after implementation of the educational program in total knowledge with $(\mathrm{p} \leq 0.001), \&$ there was a highly statistically significant difference between pre and follow up program in the studied patients with $(\mathrm{p}<0.001)$.

Table (5): Shows that $49.2 \& 92.5 \& 85.8$ of the study patients had adequately done pursed lip breathing procedure 
Table (6): Shows that $37.5 \& 72.5 \& 65.8$ of the study patients had adequately done diaphragmatic breathing procedure.

Table (7): Shows that $61.7 \& 91.7 \& 89.2$ of the study patients had adequately done deep breathing and coughing exercise procedure.

Table (8): Shows that $89.2 \& 98.3 \& 95.8$ of the study patients had adequately done a metered dose inhaler procedure.

Table (9): Shows that $94.2 \& 96.7 \& 92.5$ of the study patients had adequately done dry powder inhaler procedure.

Table (10): Shows that, there was a highly statistically significant difference between pre and post program \& pre and follow up program in the studied patients after implementation of the educational program related to procedures pursed lip breathing, diaphragmatic breathing, deep breathing and coughing exercise and metered dose inhaler with $(p \leq 0.001)$ meanwhile there was no statistically significant difference between pre and post\& pre and follow up program in the studied sample regarding dry powder inhaler procedure with $(\mathrm{p}<0.257) \&(\mathrm{p}<0.564)$ respectively.

Table (11): Shows that, there was a highly statistically significant difference between pre and post program in the studied patients after implementation of the educational program in total practice with $(\mathrm{p} \leq 0.001) \&$ there was a highly statistically significant difference between pre and follow up program in the studied patients with $(p<0.001)$. Figure (1): shows that $65.0 \%$ of the patients were living in urban areas while $35 \%$ of them from rural areas.

Figure (2): Shows that $55.0 \%$ had hypertension, while $15 \%$ of them had renal and others disease. 
Table (1): Socio-demographic Characteristics of Patients with COPD (N=120):

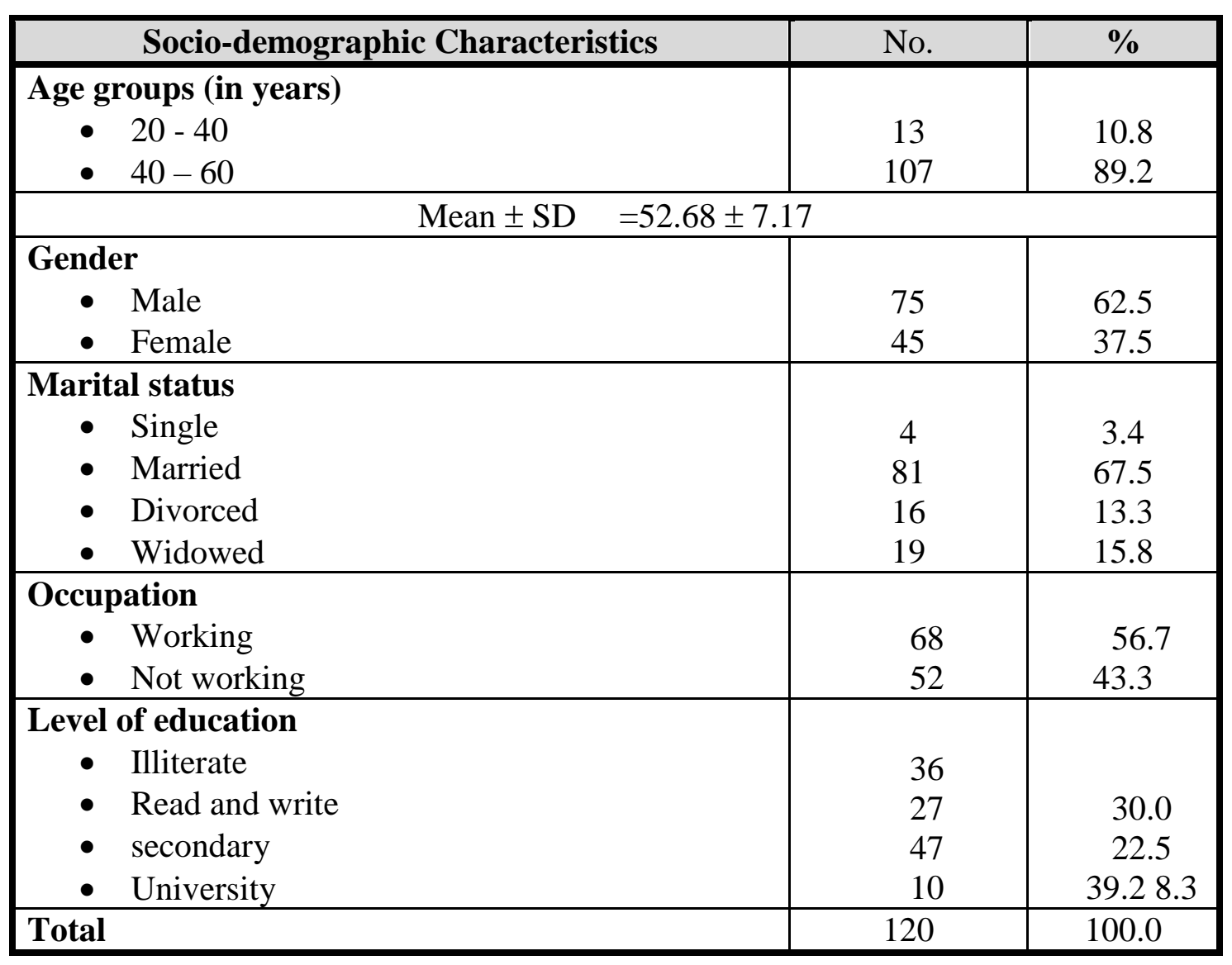

Table (2): Present Health History of Patients with COPD (N=120).

\begin{tabular}{|l|c|c|}
\hline \multicolumn{1}{|c|}{ Present health history } & No. & \% \\
\hline Duration of COPD & & \\
- Less than < 1year & 15 & 12.5 \\
- From 1 -3 years & 30 & 25.0 \\
- From 3 - 5 years & 23 & 19.2 \\
- $\geq$ 5 years & 52 & 43.3 \\
\hline Drug Compliance & & \\
- Yes & 88 & 73.3 \\
- No & 32 & 26.7 \\
\hline Chronic Disease & & \\
- Yes & 93 & 77.5 \\
- No & 27 & 22.5 \\
\hline Smoking Status: & & \\
- None smoker & 55 & 45.8 \\
- Previous smoker & 44 & 36.7 \\
- Current smoker & 21 & 17.5 \\
\hline Smoking Type: & & \\
- Cigarette smoking & 52 & 43.3 \\
- Shisha & 5 & 4.2 \\
- Both & 8 & 6.7 \\
\hline
\end{tabular}


Table (3): Past and Family Health History of Patients with COPD (N=120).

\begin{tabular}{|l|c|c|}
\hline \multicolumn{1}{|c|}{ Past and Family health history } & No. & $\%$ \\
\hline Signs and symptoms: & & \\
- Dyspnea & 85 & 70.8 \\
- Chronic cough & 85 & 70.8 \\
- Excessive sputum & 86 & 71.7 \\
- Wheezing & 56 & 46.7 \\
- Weight Loss & 34 & 28.3 \\
- Fatigue & 55 & 45.8 \\
- Cyanosis & 43 & 35.8 \\
\hline Previous hospitalization during last year: & & \\
- Once & 30 & 25.0 \\
- From 2-4 times & 45 & 37.5 \\
- More than 4 times & 36 & 30.0 \\
- No & 9 & 7.5 \\
\hline Family History of COPD: & & \\
- Yes & 31 & 25.8 \\
- No & 89 & 74.2 \\
\hline Degree of relativity & 25 & 20.8 \\
- 1 degree & 6 & 5.0 \\
- 2ndegree &
\end{tabular}

Table (4): Comparison of Patients' Total Knowledge Score before and after Program Implementation and Follow up $(\mathrm{N}=120)$.

\begin{tabular}{|c|c|c|c|c|c|c|c|c|}
\hline \multirow{3}{*}{ Item } & \multicolumn{4}{|c|}{ Total knowledge } & \multirow{2}{*}{\multicolumn{2}{|c|}{ Pre Vs post }} & \multirow{2}{*}{\multicolumn{2}{|c|}{ Pre Vs FU }} \\
\hline & \multicolumn{2}{|c|}{ Satisfactory } & \multicolumn{2}{|c|}{ Unsatisfactory } & & & & \\
\hline & No & $\%$ & No & $\%$ & $\mathbf{Z}$ & p-value & $\mathbf{Z}$ & p- value \\
\hline Pre program & 76 & 63.3 & 44 & 36.7 & \multirow{3}{*}{6.245} & \multirow{3}{*}{$<0.001 *$} & \multirow{3}{*}{4.964} & \multirow{3}{*}{$<0.001 *$} \\
\hline Post program & 115 & 95.8 & 5 & 4.2 & & & & \\
\hline Follow up & 107 & 89.2 & 13 & 10.8 & & & & \\
\hline
\end{tabular}

Not significant $>\mathbf{0 . 0 5}(\mathrm{NS}) \quad *$ Significance $\leq \mathbf{0 . 0 5}(\mathrm{S}) \quad * *$ Highly Significance $\leq$ 0.001 (HS) 
Table (5): Practice Scores of Patients with COPD Regarding Pursed lip breathing Procedure $(\mathrm{N}=120)$ :

\begin{tabular}{|c|c|c|c|c|c|c|c|c|c|c|c|c|}
\hline \multirow{3}{*}{$\begin{array}{l}\text { Procedure } \\
\text { (1) }\end{array}$} & \multicolumn{4}{|c|}{ Pre } & \multicolumn{4}{|c|}{ Post } & \multicolumn{4}{|c|}{$\overline{\mathrm{FU}}$} \\
\hline & \multicolumn{2}{|c|}{$\begin{array}{c}\text { Inadequate } \\
\text { ly done }\end{array}$} & \multicolumn{2}{|c|}{$\begin{array}{c}\text { Adequate } \\
\text { ly done }\end{array}$} & \multicolumn{2}{|c|}{$\begin{array}{c}\text { Inadequate } \\
\text { ly done }\end{array}$} & \multicolumn{2}{|c|}{$\begin{array}{c}\text { Adequatel } \\
\text { y done }\end{array}$} & \multicolumn{2}{|c|}{$\begin{array}{c}\text { Inadequ } \\
\text { ately } \\
\text { done }\end{array}$} & \multicolumn{2}{|c|}{$\begin{array}{c}\text { Adequately } \\
\text { done }\end{array}$} \\
\hline & No & $\%$ & No & $\%$ & No & $\%$ & No & $\%$ & $\begin{array}{l}\mathbf{N} \\
\mathbf{0}\end{array}$ & $\%$ & No & $\%$ \\
\hline Step(1) & 115 & 95.8 & 5 & 4.2 & 44 & 36.7 & 76 & 63.3 & 46 & $\begin{array}{r}38 \\
.3\end{array}$ & 74 & 61.7 \\
\hline Step(2) & 56 & 46.7 & 64 & 53.3 & 6 & 5 & 114 & 95 & 10 & $\begin{array}{l}8 . \\
3\end{array}$ & 110 & 91.7 \\
\hline Step(3) & 58 & 48.3 & 62 & 51.7 & 15 & 12.5 & 105 & 87.5 & 19 & $\begin{array}{r}15 \\
.8\end{array}$ & 101 & 84.2 \\
\hline Step(4) & 57 & 47.5 & 63 & 52.5 & 14 & 11.7 & 106 & 88.3 & 22 & $\begin{array}{r}18 \\
.3\end{array}$ & 98 & 81.7 \\
\hline Total & 61 & 50.8 & 59 & 49.2 & 9 & 7.5 & 111 & 92.5 & 17 & $\begin{array}{l}14 \\
.2 \\
\end{array}$ & 103 & 85.8 \\
\hline
\end{tabular}

Table (6): Practice Scores of Patients with COPD Regarding diaphragmatic breathing Procedure $(\mathrm{N}=120$

\begin{tabular}{|c|c|c|c|c|c|c|c|c|c|c|c|c|}
\hline \multirow{2}{*}{$\begin{array}{c}\text { Procedure } \\
(\mathbf{2})\end{array}$} & \multicolumn{4}{|c|}{ Pre } & \multicolumn{4}{c|}{ Post } & \multicolumn{4}{c|}{ FU } \\
\cline { 2 - 13 } & $\begin{array}{c}\text { Inadequately } \\
\text { done }\end{array}$ & $\begin{array}{c}\text { Adequately } \\
\text { done }\end{array}$ & $\begin{array}{c}\text { Inadequately } \\
\text { done }\end{array}$ & $\begin{array}{c}\text { Adequately } \\
\text { done }\end{array}$ & $\begin{array}{c}\text { Inadequately } \\
\text { done }\end{array}$ & $\begin{array}{c}\text { Adequately } \\
\text { done }\end{array}$ \\
\cline { 2 - 14 } & No & No & \% & No & \% & No & $\%$ & No & $\%$ & No & $\%$ \\
\hline Step (1) & 82 & 68.3 & 38 & 31.7 & 22 & 18.3 & 98 & 81.7 & 21 & 17.5 & 99 & 82.5 \\
\hline Step (2) & 59 & 49.2 & 61 & 50.8 & 29 & 24.2 & 91 & 75.8 & 27 & 22.5 & 93 & 77.5 \\
\hline Step (3) & 36 & 30 & 84 & 70 & 31 & 25.8 & 89 & 74.2 & 39 & 32.5 & 81 & 67.5 \\
\hline Step (4) & 37 & 30.8 & 83 & 69.2 & 33 & 27.5 & 87 & 72.5 & 41 & 34.2 & 79 & 65.8 \\
\hline Step (5) & 32 & 26.7 & 88 & 73.3 & 30 & 25 & 90 & 75 & 38 & 31.7 & 82 & 68.3 \\
\hline Step (6) & 59 & 49.2 & 61 & 50.8 & 25 & 20.8 & 95 & 79.2 & 35 & 29.2 & 85 & 70.8 \\
\hline Step (7) & 117 & 97.5 & 3 & 2.5 & 46 & 38.3 & 74 & 61.7 & 41 & 34.2 & 79 & 65.8 \\
\hline Total & 75 & 62.5 & 45 & 37.5 & 33 & 27.5 & 87 & 72.5 & 41 & 34.2 & 79 & 65.8 \\
\hline
\end{tabular}


Table (7): Practice Scores of Patients with COPD Regarding deep breathing and coughing exercise Procedure $(\mathrm{N}=120)$ :

\begin{tabular}{|c|c|c|c|c|c|c|c|c|c|c|c|c|}
\hline \multirow{3}{*}{$\begin{array}{c}\text { Procedure } \\
\text { (3) }\end{array}$} & \multicolumn{4}{|c|}{ Pre } & \multicolumn{4}{|c|}{ Post } & \multicolumn{4}{|c|}{$\mathbf{F U}$} \\
\hline & \multicolumn{2}{|c|}{$\begin{array}{c}\text { Inadequately } \\
\text { done }\end{array}$} & \multicolumn{2}{|c|}{$\begin{array}{c}\text { Adequately } \\
\text { done }\end{array}$} & \multicolumn{2}{|c|}{$\begin{array}{c}\text { Inadequately } \\
\text { done }\end{array}$} & \multicolumn{2}{|c|}{$\begin{array}{c}\text { Adequately } \\
\text { done }\end{array}$} & \multicolumn{2}{|c|}{$\begin{array}{c}\text { Inadequately } \\
\text { done }\end{array}$} & \multicolumn{2}{|c|}{$\begin{array}{c}\text { Adequatel } \\
\text { done }\end{array}$} \\
\hline & No & $\%$ & No & $\%$ & No & $\%$ & No & $\%$ & No & $\%$ & No & $\%$ \\
\hline Step(1) & 115 & 95.8 & 5 & 4.2 & 6 & 5 & 114 & 95 & 6 & 5 & 114 & 95 \\
\hline Step(2) & 48 & 40 & 72 & 60 & 22 & 18.3 & 98 & 81.7 & 28 & 23.3 & 92 & 76.7 \\
\hline Step(3) & 22 & 18.3 & 98 & 81.7 & 18 & 15 & 102 & 85 & 21 & 17.5 & 99 & 82.5 \\
\hline Step(4) & 33 & 27.5 & 87 & 72.5 & 24 & 20 & 96 & 80 & 30 & 25 & 90 & 75 \\
\hline Step(5) & 47 & 39.2 & 73 & 60.8 & 37 & 30.8 & 83 & 69.2 & 37 & 30.8 & 83 & 69.2 \\
\hline Total & 46 & 38.3 & 74 & 61.7 & 10 & 8.3 & 110 & 91.7 & 13 & 10.8 & 107 & 89.2 \\
\hline
\end{tabular}

Table (8): Practice Scores of Patients with COPD Regarding A metered dose inhaler

Procedure $(\mathrm{N}=120)$ :

\begin{tabular}{|c|c|c|c|c|c|c|c|c|c|c|c|c|}
\hline \multirow{3}{*}{$\begin{array}{l}\text { Procedur } \\
\text { e }\end{array}$} & \multicolumn{4}{|c|}{ Pre } & \multicolumn{4}{|c|}{ Post } & \multicolumn{4}{|c|}{ FU } \\
\hline & \multicolumn{2}{|c|}{$\begin{array}{c}\text { Inadequatel } \\
\text { y done }\end{array}$} & \multicolumn{2}{|c|}{$\begin{array}{l}\text { Adequatel } \\
\text { y done }\end{array}$} & \multicolumn{2}{|c|}{$\begin{array}{c}\text { Inadequatel } \\
\text { y done }\end{array}$} & \multicolumn{2}{|c|}{$\begin{array}{l}\text { Adequatel } \\
\text { y done }\end{array}$} & \multicolumn{2}{|c|}{$\begin{array}{c}\text { Inadequatel } \\
\text { y done }\end{array}$} & \multicolumn{2}{|c|}{$\begin{array}{c}\text { Adequatel } \\
\text { y done }\end{array}$} \\
\hline & No & $\%$ & No & $\%$ & No & $\%$ & No & $\%$ & No & $\%$ & No & $\%$ \\
\hline $\operatorname{Step}(1)$ & 11 & 9.2 & 109 & 90.8 & 10 & 8.3 & 110 & 91.7 & 11 & 9.2 & 109 & 90.8 \\
\hline Step $(2)$ & 10 & 8.3 & 110 & 91.7 & 9 & 7.5 & 111 & 92.5 & 10 & 8.3 & 110 & 91.7 \\
\hline Step(3) & 43 & 35.8 & 77 & 64.2 & 22 & 18.3 & 98 & 81.7 & 23 & 19.2 & 97 & 80.8 \\
\hline Step(4) & 12 & 10 & 108 & 90 & 4 & 3.3 & 116 & 96.7 & 4 & 3.3 & 116 & 96.7 \\
\hline Step(5) & 12 & 10 & 108 & 90 & 4 & 3.3 & 116 & 96.7 & 6 & 5 & 114 & 95 \\
\hline Step(6) & 15 & 12.5 & 105 & 87.5 & 7 & 5.8 & 113 & 94.2 & 10 & 8.3 & 110 & 91.7 \\
\hline Step(7) & 71 & 59.2 & 49 & 40.8 & 1 & 0.8 & 119 & 99.2 & 1 & 0.8 & 119 & 99.2 \\
\hline Step $(8)$ & 14 & 11.7 & 106 & 88.3 & 0 & 0 & 120 & 100 & 0 & 0 & 120 & 100 \\
\hline Step(9) & 14 & 11.7 & 106 & 88.3 & 0 & 0 & 120 & 100 & 0 & 0 & 120 & 100 \\
\hline Step(10) & 62 & 51.7 & 58 & 48.3 & 25 & 20.8 & 95 & 79.2 & 25 & 20.8 & 95 & 79.2 \\
\hline Total & 13 & 10.8 & 107 & 89.2 & 2 & 1.7 & 118 & 98.3 & 5 & 4.2 & 115 & 95.8 \\
\hline
\end{tabular}


Table (9): Practice Scores of Patients with COPD Regarding dry powder inhaler Procedure $(\mathrm{N}=120)$ :

\begin{tabular}{|c|c|c|c|c|c|c|c|c|c|c|c|c|}
\hline \multirow{3}{*}{$\begin{array}{c}\text { Procedur } \\
\text { e } \\
(5)\end{array}$} & \multicolumn{4}{|c|}{ Pre } & \multicolumn{4}{|c|}{ Post } & \multicolumn{4}{|c|}{$\mathbf{F U}$} \\
\hline & \multicolumn{2}{|c|}{$\begin{array}{c}\text { Inadequatel } \\
\text { y done }\end{array}$} & \multicolumn{2}{|c|}{$\begin{array}{l}\text { Adequatel } \\
\text { y done }\end{array}$} & \multicolumn{2}{|c|}{$\begin{array}{c}\text { Inadequatel } \\
\text { y done }\end{array}$} & \multicolumn{2}{|c|}{$\begin{array}{l}\text { Adequatel } \\
\text { y done }\end{array}$} & \multicolumn{2}{|c|}{$\begin{array}{c}\text { Inadequatel } \\
y \text { done }\end{array}$} & \multicolumn{2}{|c|}{$\begin{array}{c}\text { Adequatel } \\
\text { y done }\end{array}$} \\
\hline & No & $\%$ & No & $\%$ & No & $\%$ & No & $\%$ & No & $\%$ & No & $\%$ \\
\hline Step(1) & 32 & 26.7 & 88 & 73.3 & 24 & 20 & 96 & 80 & 28 & 23.3 & 92 & 76.7 \\
\hline $\operatorname{Step}(2)$ & 19 & 15.8 & 101 & 84.2 & 11 & 9.2 & 109 & 90.8 & 15 & 12.5 & 105 & 87.5 \\
\hline Step(3) & 21 & 17.5 & 99 & 82.5 & 6 & 5 & 114 & 95 & 11 & 9.2 & 109 & 90.8 \\
\hline Step(4) & 9 & 7.5 & 111 & 92.5 & 5 & 4.2 & 115 & 95.8 & 10 & 8.3 & 110 & 91.7 \\
\hline Step (5) & 7 & 5.8 & 113 & 94.2 & 4 & 3.3 & 116 & 96.7 & 9 & 7.5 & 111 & 92.5 \\
\hline $\operatorname{Step}(6)$ & 6 & 5 & 114 & 95 & 4 & 3.3 & 116 & 96.7 & 9 & 7.5 & 111 & 92.5 \\
\hline Step(7) & 5 & 4.2 & 115 & 95.8 & 5 & 4.2 & 115 & 95.8 & 10 & 8.3 & 110 & 91.7 \\
\hline Step $(8)$ & 5 & 4.2 & 115 & 95.8 & 5 & 4.2 & 115 & 95.8 & 10 & 8.3 & 110 & 91.7 \\
\hline Step(9) & 7 & 5.8 & 113 & 94.2 & 4 & 3.3 & 116 & 96.7 & 9 & 7.5 & 111 & 92.5 \\
\hline Total & 7 & 5.8 & 113 & 94.2 & 4 & 3.3 & 116 & 96.7 & 9 & 7.5 & 111 & 92.5 \\
\hline
\end{tabular}

Table (10): Impact of the Educational Program on Patients' Practice before and after Implementation of the Educational Program and Follow Up.

\begin{tabular}{|c|c|c|c|c|c|c|c|c|c|c|}
\hline \multirow{2}{*}{ Items } & \multicolumn{2}{|c|}{ Pre } & \multicolumn{2}{|c|}{ Post } & \multicolumn{2}{|c|}{ FU } & \multicolumn{2}{|c|}{ Pre Vs. Post } & \multicolumn{2}{|c|}{ Pre Vs. FU } \\
\hline & No & $\%$ & No & $\%$ & No & $\%$ & $\mathbf{Z}$ & $\mathbf{P}$ & $\mathbf{Z}$ & $\mathbf{P}$ \\
\hline \multicolumn{11}{|c|}{ Pursed Lip Breathing } \\
\hline Adequately done & 59 & 49.2 & 111 & 92.5 & 103 & 85.8 & \multirow{2}{*}{-7.076} & \multirow{2}{*}{$<0.001 *$} & \multirow{2}{*}{-6.102} & \multirow{2}{*}{$<0.001 *$} \\
\hline In adequately done & 61 & 50.8 & 9 & 7.5 & 17 & 14.2 & & & & \\
\hline \multicolumn{11}{|c|}{ Diaphragmatic Breathing } \\
\hline Adequately done & 45 & 37.5 & 87 & 72.5 & 79 & 65.8 & \multirow{2}{*}{-6.481} & \multirow{2}{*}{$<0.001^{*}$} & \multirow{2}{*}{-5.246} & \multirow{2}{*}{$<0.001 *$} \\
\hline In adequately done & 75 & 62.5 & 33 & 27.5 & 41 & 34.2 & & & & \\
\hline \multicolumn{11}{|c|}{ Deep Breathing and Coughing Exercise } \\
\hline Adequately done & 74 & 61.7 & 110 & 91.7 & 107 & 89.2 & \multirow{2}{*}{-6.000} & \multirow{2}{*}{$<0.001 *$} & \multirow{2}{*}{-5.284} & \multirow{2}{*}{$<0.001 *$} \\
\hline In adequately done & 46 & 38.3 & 10 & 8.3 & 13 & 10.8 & & & & \\
\hline \multicolumn{11}{|c|}{ Metered Dose Inhaler } \\
\hline Adequately done & 107 & 89.2 & 118 & 98.3 & 115 & 95.8 & \multirow{2}{*}{-3.317} & \multirow{2}{*}{$0.001 *$} & \multirow{2}{*}{-2.530} & \multirow{2}{*}{$0.011^{*}$} \\
\hline In adequately done & 13 & 10.8 & 2 & 1.7 & 5 & 4.2 & & & & \\
\hline \multicolumn{11}{|c|}{ Dry Powder Inhaler } \\
\hline Adequately done & 113 & 94.2 & 116 & 96.7 & 111 & 92.5 & \multirow{2}{*}{-1.134} & \multirow{2}{*}{0.257} & \multirow{2}{*}{-0.577} & \multirow{2}{*}{0.564} \\
\hline In adequately done & 7 & 5.8 & 4 & 3.3 & 9 & 7.5 & & & & \\
\hline
\end{tabular}

Not significant $>\mathbf{0 . 0 5}(\mathrm{NS}) \quad *$ Significance $\leq \mathbf{0 . 0 5}(\mathrm{S}) \quad * *$ Highly Significance $\leq$ 
Table (11): Comparison of Patients' Total Practice Score before and after Program Implementation and Follow Up (N=120).

\begin{tabular}{|c|c|c|c|c|c|c|c|c|}
\hline \multirow{3}{*}{ Item } & \multicolumn{4}{|c|}{ Total practice } & \multirow{2}{*}{\multicolumn{2}{|c|}{ Pre Vs post }} & \multirow{2}{*}{\multicolumn{2}{|c|}{ Pre Vs FU }} \\
\hline & \multicolumn{2}{|c|}{$\begin{array}{c}\text { Adequately } \\
\text { Done }\end{array}$} & \multicolumn{2}{|c|}{$\begin{array}{c}\text { Inadequately } \\
\text { Done }\end{array}$} & & & & \\
\hline & No & $\%$ & No & $\%$ & $\mathbf{Z}$ & p-value & $\mathbf{Z}$ & p-value \\
\hline Pre program & 92 & 76.7 & 28 & 23.3 & \multirow{3}{*}{5.196} & \multirow{3}{*}{$<0.001 *$} & \multirow{3}{*}{5.000} & \multirow{3}{*}{$<0.001 *$} \\
\hline Post program & 119 & 99.2 & 1 & 0.8 & & & & \\
\hline Follow up & 117 & 97.5 & 3 & 2.5 & & & & \\
\hline
\end{tabular}

Not significant $>\mathbf{0 . 0 5}(\mathrm{NS}) \quad$ *Significance $\leq \mathbf{0 . 0 5}(\mathrm{S}) \quad * *$ Highly Significance $\leq$ 0.001 (HS)

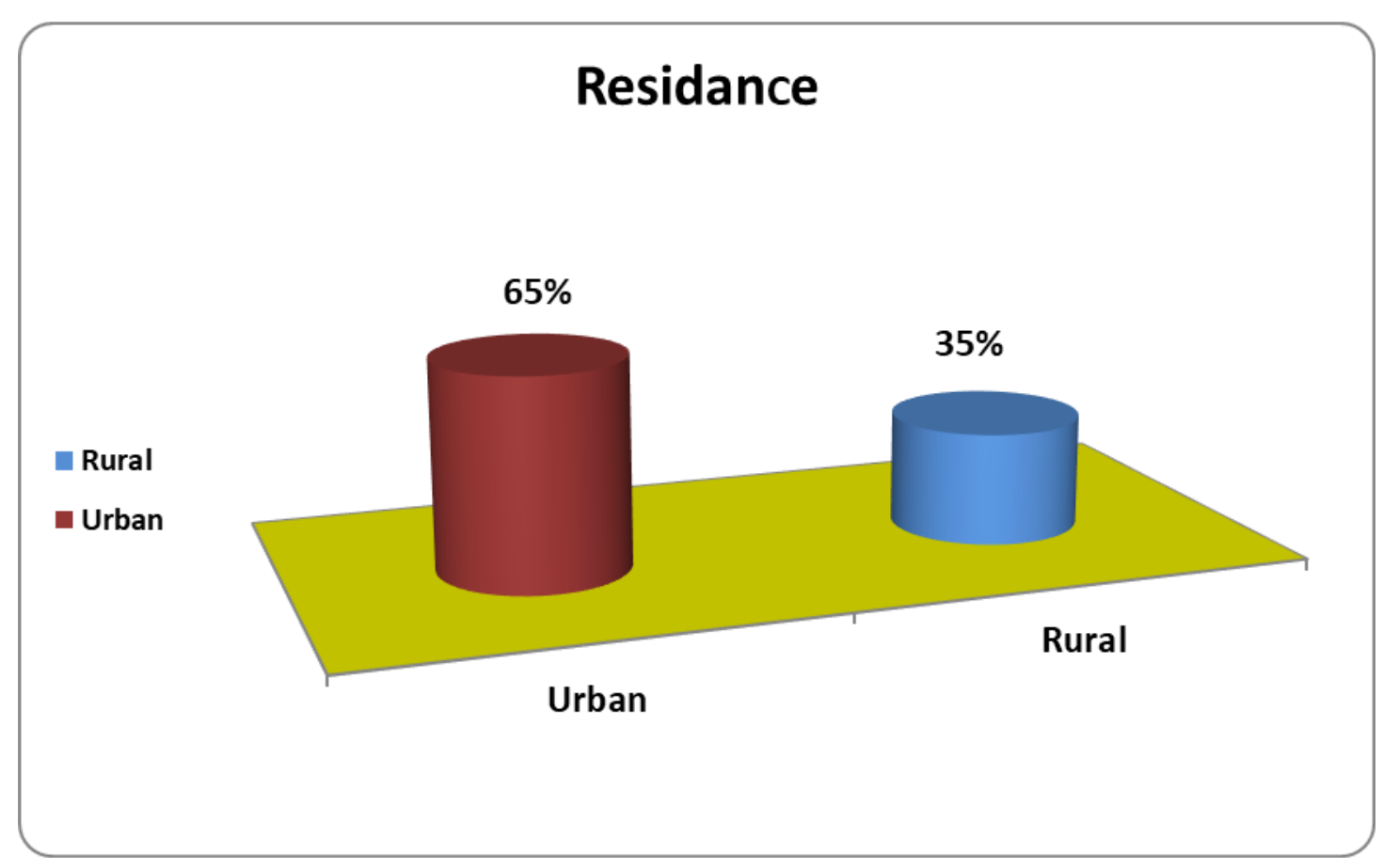

Figure (1): Distribution of Patients with COPD According to Residence. 


\section{Chroni Disease}

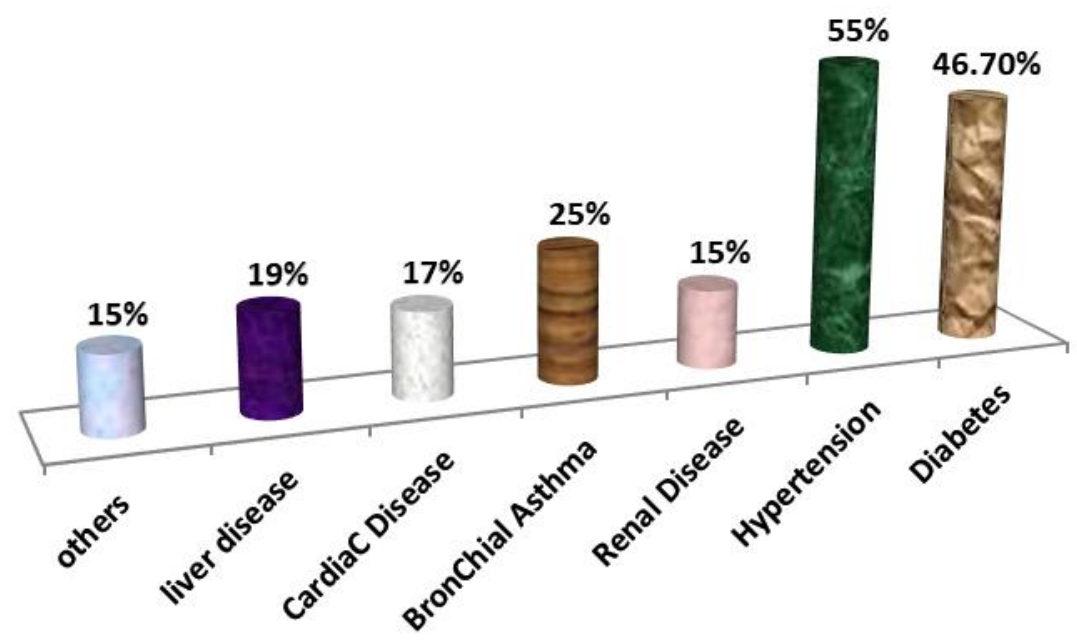

Figure (2): Distribution of Patients with COPD according to Presence of Chronic

Diseases.

\section{DISCUSSION:}

Chronic obstructive pulmonary disease is a complex, multifactorial, and progressive disease associated with significant morbidity and mortality. The rising economic burden of COPD correlates with increases in disease severity, and hospital admissions and readmissions account for a significant bulk of cost across all stages of COPD. Early appropriate behavioral and pharmacotherapy options to reduce COPD exacerbations are essential for slowing disease progression, increasing patient quality of life, and subsequently reducing the overall cost burden of this disease state (Guarascio, Ray, Finch, \& Self, 2013).

Socio demographic characteristics of the studied patients revealed that; most of the studied patients were aged between 40-60years old. with mean age $52.68 \pm$ 7.17years, These findings might be due to that COPD takes many years until serious effects of smoking on lungs appear. This is supported by (Qaseem, Wilt, Weinberger, Hanania, Criner, Van der Molen, Marciniuk, Denberg, Schünemann, Wedzicha, MacDonald, \& Shekelle, 2011) that stated that the single best variable for predicting 
which adults will have airflow obstruction on spirometry is a history of more than 40 pack years of smoking.

Also this finding is supported by (Lewis, Dirksen, Heitkemper, \& Bucher, 2014), who stated that as people age there is gradual loss of the elastic recoil of the lung. The lungs become more rounded and smaller. The number of functional alveoli decreases as peripheral airways lose supporting tissues. Changes in the elasticity of the lungs reduce the ventilatory reserve, and ability to clear secretions decreases with age.

The study finding are in agreement with (Salah, Hamdi, \& Shehata,2013) who mentioned that, the mean age of more than half of patients with COPD were 50 years of age or older. According to (Badway, Hamed, \& Yousef, 2016) the age of patients who included in their study was between 40-59 years and they represent approximately three quarters of study patients.

As regard to gender, the result of the present study showed that, near two thirds of study patients were male. This finding could be due to the higher prevalence of smoking in this gender in Egypt; also, males are more exposed to smoking than females, and occupational exposures are significant in male. This finding was supported by (Zamzam, Azab, Ragab, El Wahsh, \& Allam, 2012) who stated that, the majority of patients were males in their study entitled "Quality of Life in COPD Patients", while this finding was contradicted with (Center of Disease Control and Prevention, 2013) that reported that females are more likely to have chronic obstructive pulmonary disease than males, and with (Scott, Baltzan, Dajczman, \& Wolkove, 2011) who reported that $53 \%$ were women.

In relation to marital status, the study finding showed that, two thirds of study patients were married. This finding might be due to the same age groups of the studied sample. This finding is in accordance with (Abedi, Salimi, Feizi, \& Safari,, 2013) who found that the majority of the studied patients were married. This finding is in contrast with (Jacobsen, Rusch, Andersen, Adams, Jensen, \& Frølich, 2014) who stated that more than two thirds of the patients were single.

Regarding occupation, the current study portrayed that, more than half of the study patients were working. The researcher opinion was that this may reflect the load, the higher levels of anxiety and depression that experienced by the patients through their role in caring for their families and to cover high cost of medications. The married 
patients are suffering because they may feel that, they were a burden on their partners because of the limitations in their expected roles toward their family (Mohamed, Ahmed, Mohamed, \& Abdel Rah man, 2016). This finding is in agreement with (Farag, Hafez, Elshafie, \&Abo-Elkheir, 2012) who reported that three quarters (75\%) of studied patients were working.

Concerning to educational level, the current study portrayed that, About two fifth of studied pateints had secondary education, about one third of them were illiterate, While minority of them had completed university degree. This finding is in agreement with (Bratas, Espnes, Rannestad, \& Walstad, 2010) who reported that $13.2 \%$ of studied patients had university degree, and (Farag, et al., 2012) who reported that $41 \%$ of studied patients were illiterate. This finding is in contrast with (Mohamed, 2005) who stated that, two fifth of the study group had high level education, while few of them were illiterate, and (Subba \& Subba, 2015) who stated that (65.4\%) were illiterate.

Regarding residence, the current study showed that, near to two thirds of the studied patients were lived in urban areas. This is in accordance with (Lidia, 2012) who reported the same result (65\%), and with (Mohamed, et al., 2016) who stated that more than half of the studied patients were lived in urban areas. This result shows the crowdedness, pollution and poor houses ventilation that those patients live in and confirm that outdoor and indoor pollutions are risk factors for developing the disease. But the same finding is contradicted with that of (Badway, et al., 2016) who stated that one quarter of their study patients were living in urban and three quarters were living in rural areas.

Concerning duration of COPD, the current study revealed that about half of the studied patients had COPD for more than five years. This finding is in agreement with (Belletti, Liu, Zacker, \& Wogen, 2013) who found that, mean duration of COPD was approximately 4.8 years and with (Hernandez, Balter, Bourbeau, \&Hodder, 2009) who found that fifty-one percent of the patients were diagnosed with COPD greater than 5 years. These findings reflect the chronicity of the disease.

Concerning drug compliance, the present study illustrated that about three quarters of studied patients were compliant to medication. This finding isn't in accordance with (Reema, Adepu, \&Sabin, 2010) who stated that most COPD patients were not on regular treatment and took medication only during acute exacerbation and 
with (Krigsman, Nilsson, \& Ring, 2007) who stated that average of $60 \%$ of patients with COPD do not adhere to prescribed therapy.

(Jones, Hyland, Hanney, \& Erwin, 2004) in a qualitative study of compliance to medication and lifestyle modification in patients with COPD found that all patients except one reported good adherence to medication.

The researcher opinion include that factors such as fear of dyspnea and feelings of vulnerability appear to contribute to improvement in compliance. This is supported by (Restrepo, Alvarez, \& Wilkins, 2008)who stated that Patients' acceptance and knowledge of the disease process as well as the recommended treatment, faith in the treatment, effective patient - clinician interaction are all critical for optimal medication adherence in patients with COPD

Concerning chronic diseases, the present study illustrated that more than three quarter of the studied patients had associated chronic diseases such as diabetes, hypertension, bronchial asthma, liver, cardiac, and renal diseases. This finding is in accordance with (Belletti, et al., 2013) and (Akazawa, Stearns, \& Biddle, 2008) who stated that, the majority of COPD patients had chronic diseases in the form of co morbid asthma, hypertension, dyslipidemia, cardiovascular disease, and diabetes. These findings are supported by (Global Initiative for Chronic Obstructive Lung Disease, 2016) that revealed that COPD often co exists with other diseases (co morbidities) that may have a significant impact on prognosis.

As regard to smoking status, the present study illustrated that more than half of studied patients were smokers; about two fifth of them were previous smokers while about one fifth of them were current smokers. This finding is in accordance with (Kupryś-Lipińska \& Kuna, 2014) and (Antwi, Steck, \&Heidari, 2013) who found the same result. While this finding is in contrast with (Fu, Yu, Wong, \& Lam, 2016) who indicated that approximately half of them were current smokers. This finding is in the same line with the fact that, smoking is a major risk factor for COPD.

Concerning to smoking type, the present study illustrated that near half of smokers were cigarettes smokers, while minority of them were smoking shisha or both. This finding is in agreement with (Mahmud, Bokhari, \& Aasim, 2012) who found the same result. These findings are supported by (Global Initiative for Chronic Obstructive Lung Disease, 2016) that stated that cigarette smoking is the best-studied COPD risk 
factor, moreover cigarette smokers have a higher prevalence of respiratory symptoms and lung function abnormalities, a greater annual rate of decline in FEV1, and a greater COPD mortality rate than nonsmokers.

Regarding signs and symptoms of COPD, the present study revealed that, about three quarter of studied patients had dyspnea, chronic cough, and excessive sputum, near half of them had wheezing, fatigue, and cyanosis, and more than one quarter of them were suffering weight loss. This finding is in agreement with (Bentsen, gundersen, dassmus, bringsvor, \& Berland, 2013) and (Hernandez, et al., 2009) who mentioned that most frequently reported symptoms of patients with COPD to occur "every day" or "most days" included coughing, bringing up of sputum, and shortness of breath. These results also supported by (Global Initiative for Chronic Obstructive Lung Disease, 2016) that stated that cough, dyspnea, and sputum are common manifestations of COPD.

As regard to previous hospitalization, the present study revealed that most of studied patients had been previously hospitalized from 1 to more than 4 times during previous year of study. The researcher opinion might be due to the increasing frequency and severity of exacerbations which are provoked by exposure to irritants and pollutants in addition to frequent respiratory tract infection.

This finding is in accordance with (Mohamed, 2005) who stated that majority of COPD patients were previously admitted to hospital, and (Baghai-Ravary, Quint, Goldring, Hurst, JDonaldson, \& Wedzicha, 2009) who stated that, hospitalization rates in the patients with COPD are high, and increase with age. Also (Subba \& Subba, 2015) stated that $83.2 \%$ were hospitalized 1-2 times in last year. However this finding is in contrary with (Salah, et al., 2013) who stated that $68.0 \%$ of patients weren't hospitalized before.

As regard to family history of COPD, the present study illustrated that more than one quarter of studied patients had positive family history of COPD with a first degree relativity. This finding is in accordance with (Hernandez, Balter, Bourbeau, Chan, Marciniuk, \& Walker, 2013) who stated that there was a significant number of COPD patients reported a positive family history of COPD, and with (Stavngaard, Shaker, \&Dirksen, 2006) who stated that half of patients had alpha1-antitrypsin deficiency. These findings are supported by (Global Initiative for Chronic Obstructive Lung 
Disease, 2016) who revealed that although alpha 1-antitrypsin deficiency is relevant only to small part of the world's population, it illustrates the interaction between genes and environment.

Regarding patients' knowledge about COPD and its management, the results of this study showed that there was highly statistically significant difference between mean score of total knowledge related to COPD pre \& post implementation of the educational program and pre $\&$ follow up ( $\mathrm{p} \leq 0.001)$. On the same line (Salah et al., 2013) stated that, none of the studied patients in their study had satisfactory level of knowledge pre intervention however, the majority of them had satisfactory level of knowledge post intervention $(\mathrm{p}<0.001)$.

The current study results are in accordance with (Paneroni, Clini, Crisafulli, Guffanti, Fumagalli, Bernasconi, Cabiaglia, Nicolini, Brogi, Ambrosino, Peroni, Bianchi, \& Vitacca, 2013) who stated that COPD knowledge, rehabilitation, and healthy lifestyles areas can be significantly improved after an educational intervention.

This result may reflect the positive effect of the management guidelines. This might be due to that this knowledge is of great importance for the patient, also, unavailability of this knowledge through the health care team in the hospital. This result was congruent with (Cleary\& Serisier, 2012) who stated that, many people who are first diagnosed with COPD report feeling confused and worried, that are relieved when they have an explanation and more information for their breathlessness and other symptoms.

Regarding patients' level of practice pre \& post educational program implementation and pre \& follow up, the study revealed presence of highly statistically significant improvement in all items of practice $(p \leq 0.001)$, except that related to dry powder inhaler, This might be due to the unfamiliarity of some patients with this type of management. This result is consistent with (Ries, Bauldoff, Carlin, Casaburi, Emery, \& Mahler, 2007) who mentioned that, coping with a chronic condition involves skills training, learning to manage a number of symptoms, and consciously assessing and making lifestyle changes.

The researcher opinion toward this finding regarding inhaler might be due to this technique is one of the basic procedures that must be done as obligatory teaching to the patient on the first session with health care providers. This finding goes in the same line with (Souza, Meneghini, Ferraz, Vianna, \& Borges, 2009) who reported nearly all of the 
COPD patients claimed to know how to use inhalation devices correctly, and with (Hernandez, et al., 2009) who stated that inhalers were reported as effective by $89 \%$ of respondents.

This finding is in contrast with (Reema, eta 1., 2010) who revealed that, although all patients shook the canister before using the medication, none of them had proper inhalation technique, and with (Serra-Batlles, Plaza, Badiola, \& Morejón, 2002) who stated that up to $85 \%$ of COPD patients use their inhaler ineffectively.

This results is highly supported with (Mohamed, et al., 2016) who stated that, there were highly statistically significant differences between mean score of total patients' practice pre and post implementation of COPD care protocol. Also (Salah, et al., 2013) stated that there were a highly significant improvement post guidelines implementation regarding breathing exercise and inhaler uses.

\section{CONCLUSION:}

Results of this study concluded that after pretest, patients had good knowledge regarding to COPD and good practices, but after implementation of the educational program, remarkable improvements were occurred in knowledge and practice.

\section{RECOMMENDATIONS:}

Continuous educational programs for patients with COPD and their family about COPD management, complication, and ways of prevention. Prospective follow up studies are warranted to develop and refine interventions to improve patient's adherence to treatment and prevent further deterioration. Recommendation concerning Ministry of Health (MOH) activities, hospitals and specialized centers' activities and increase awareness among the population at risk and general population. Also suggested guidelines should be available to improve nurse's knowledge and performance toward advanced technology and management of patients with COPD and encourage them to teach about everything they need about COPD.

\section{REFERENCES:}

Abedi, H., Salimi, S. J., Feizi, A., \& Safari, S. (2013). Effect of self-efficacy enhancement program on self-care behaviors in chronic obstructive pulmonary disease. Iranian Journal of Nursing and Midwifery Research, 18(5), 421-424

Akazawa, M., Stearns, S. C., \& Biddle, A. K. (2008). Assessing treatment effects of inhaled corticosteroids on medical expenses and exacerbations among COPD 
patients: longitudinal analysis of managed care claims. Health services research, 43(6), 2164-2182.

Antwi, S., Steck, S., and Heidari, K. (2013). Association between prevalence of chronic obstructive pulmonary disease and health-related quality of life, South Carolina, 2011. Preventing chronic disease, 10.

Badway, M. S., Hamed, A. F., \& Yousef, F. M. (2016). Prevalence of chronic obstructive pulmonary disease (COPD) in Qena Governorate. Egyptian Journal of Chest Diseases and Tuberculosis, 65(1), 29-34.

Baghai-Ravary, R., Quint, J. K., Goldring, J. J., Hurst, J. R., Donaldson, G. C., \& Wedzicha, J. A. (2009). Determinants and impact of fatigue in patients with chronic obstructive pulmonary disease. Respiratory medicine, 103(2), 216-223.

Belletti, D., Liu, J., Zacker, C., \& Wogen, J. (2013). Results of the CAPPS: COPD-assessment of practice in primary care study. Current medical research and opinion, 29(8), 957-966

Bentsen, S. B., Gundersen, D., Assmus, J., Bringsvor, H., \& Berland, A. (2013). Multiple symptoms in patients with chronic obstructive pulmonary disease in Norway. Nursing \& health sciences, 15(3), 292-299

Bratås, O., Espnes, G. A., Rannestad, T., \& Walstad, R. (2010). Characteristics of patients with chronic obstructive pulmonary disease choosing rehabilitation. Journal of rehabilitation medicine, 42(4), 362-367.

Centers for Disease Control and Prevention (2013). Chronic obstructive pulmonary disease. Retrieved May 3, 2014 From: http://www.cdc.gov/copd.

Chinet, T., Dumoulin, J., Honore, I., Braun, J. M., Couderc, L. J., Febvre, M., Mangiapan, G., Maurer, C., Serrier, P., Soyez, F., \& Terrioux, P., \& Jebrak, G. (2016). [The place of inhaled corticosteroids in COPD]. Revue des maladies respiratoires, 33 (15),877-891.

Cleary, M.\& Serisier, D. (2012). Better Living with Chronic Obstructive Pulmonary Disease: A Patient Guide ( $2^{\text {nd }}$ ed.). the Australian Lung Foundation, Queensland Government. 
Cosgrove, D., MacMahon, J., Bourbeau, J., Bradley, J. M., \& O’Neill, B. (2013). Facilitating education in pulmonary rehabilitation using the Living Well with COPD programme for pulmonary rehabilitation: a process evaluation. BMC pulmonary medicine, 13(1), 1.

Decramer, M., Janssens, W., \& Miravitlles, M. (2012). Chronic obstructive pulmonary disease. Lancet, 379(9823), 1341-51.

Farag, T. S., Hafez, M. R., Elshafie, T., \& Abo-Elkheir, O. I. (2012). Anxiety and depression among patients with Bronchial asthma, chronic obstructive pulmonary disease and diffuse parenchymatous lung diseases. Egyptian Journal of Hospital Medicine, 49, 718-731.

Fu, S. N., Yu, W. C., Wong, C. K. H., \& Lam, M. C. H. (2016). Prevalence of undiagnosed airflow obstruction among people with a history of smoking in a primary care setting. International Journal of Chronic Obstructive Pulmonary Disease, 11, 2391-2399.

Global Initiative for Chronic Obstructive Lung Disease (GOLD) (2016). The Global Strategy for the Diagnosis, Management and Prevention of COPD. Retrieved February 26, 2016 from: http://www.goldcopd. org/ .

Guarascio, A. J., Ray, S. M., Finch, C. K., \& Self, T. H. (2013). The clinical and economic burden of chronic obstructive pulmonary disease in the USA. Clinico Economics and outcomes research: CEOR, 5, 235-245.

Hernandez, P., Balter, M. S., Bourbeau, J., Chan, C. K., Marciniuk, D. D., \& Walker, S. L. (2013). Canadian practice assessment in chronic obstructive pulmonary disease: respiratory specialist physician perception versus patient reality. Canadian Respiratory Journal, 20(2), 97-105.

Hernandez, P., Balter, M., Bourbeau, J., \& Hodder, R. (2009). Living with chronic obstructive pulmonary disease: a survey of patients' knowledge and attitudes. Respiratory medicine, 103(7), 1004-1012.

Jacob, A., Rekha, R., \& Tarachand, J. (2010). Clinical Nursing Procedures: The Art of Nursing Practice. ( $2^{\text {nd }}$ ed.).Mcgraw-Hill. 
Jacobsen, R., Rusch, E., Andersen, P. K., Adams, J., Jensen, C. R., \& Frølich, A. (2014). The effect of rehabilitation on health-care utilisation in COPD patients in Copenhagen. The clinical respiratory journal, 8(3), 321-329..

Jones, R. C. M., Hyland, M. E., Hanney, K., \& Erwin, J. (2004). A qualitative study of compliance with medication and lifestyle modification in Chronic Obstructive Pulmonary Disease (COPD). Primary Care Respiratory Journal, 13(3), 149-154.

Karner, C., Chong, J., \& Poole, P. (2014). Tiotropium versus placebo for chronic obstructive pulmonary disease. The Cochrane Library,(7).

Krigsman, K., Nilsson, J. L. G., \& Ring, L. (2007). Adherence to multiple drug therapies: refill adherence to concomitant use of diabetes and asthma/COPD medication. Pharmacoepidemiology and drug safety, 16(10), 1120-1128.

Kupryś-Lipińska, I. \&Kuna, P. (2014). Impact of Chronic Obstructive Pulmonary Disease (COPD) on Patient's Life and his Family. Pneumonol Alergol Pol,82(2),82-95.

Lewis, S. L., Dirksen, S. R., Heitkemper, M. M., \& Bucher, L. (2014). Medicalsurgical nursing: assessment and management of clinical problems $\left(9^{\text {th }}\right.$ ed.), single volume. Elsevier Health Sciences.

Lidia, A.D. (2012). Respiratory Rehabilitation in Chronic Obstructive Bronchopneumonia (phD thesis, University of Medicine and Pharmacy of Craiova) Derieved from: http://www.umfcv.ro/files/r/e/Respiratory\%20rehabilitation\%20in\%20chronic\%20obstr uctive\%20bronchopneumonia.pdf.

Lodewijckx, C., Sermeus, W., Panella, M., Deneckere, S., Leigheb, F., Troosters, T., Boto, P., Mendes, R., Decramer, M., \& Vanhaecht, K. (2013). Quality indicators for in-hospital management of exacerbation of chronic obstructive pulmonary disease: results of an international Delphi study. Journal of advanced nursing, 69(2), 348-362.

Lomborg, B. (2013). Global problems, smart solutions: costs and benefits. ( $1^{\text {st }}$ ed.).New York, Cambridge University Press. 
Mahmud, T., Bokhari, S. N., \& Aasim, M. (2012). Comparison of frequency of undiagnosed chronic obstructive pulmonary disease in current or former tobacco smokers having ischemic heart diseaseIndian J Chest Dis Allied Sci, 54(2),111-6.

Mohamed, A. (2005). Pulmonary Rehabilitation: Self-care Strategies for Chronic Obstructive Pulmonary Disease Patients. (Unpublished doctorate thesis).Medical Surgical Nursing Department Faculty of Nursing, Ain Shams University.

Mohamed, D. M., Ahmed, S. S., Mohamed, A. H., \& Rahman, A. A. A. (2016). Effect of care protocol on the knowledge, practice and clinical outcomes of patients with chronic obstructive pulmonary disease. Journal of Nursing Education and Practice, 7(2), p107.

Monninkhof, E., Van der Valk, P., Van der Palen, J., Van Herwaarden, C., Partridge, M. R., \& Zielhuis, G. (2003). Self-management education for patients with chronic obstructive pulmonary disease: a systematic review. Thorax, 58(5), 394-398.

Paneroni, M., Clini, E., Crisafulli, E., Guffanti, E., Fumagalli, A., Bernasconi, A., Cabiaglia, A., Nicolini, A., Brogi, S., Ambrosino, N., Peroni, R., Bianchi, L., \& Vitacca, M. (2013). Feasibility and effectiveness of an educational program in Italian COPD patients undergoing rehabilitation. Respiratory care, 58(2), 327-333.

Prevention of COPD. Retrieved February 26, 2016 from: http://www.goldcopd. org/ .

Qaseem, A., Wilt, T. J., Weinberger, S. E., Hanania, N. A., Criner, G., Van der Molen, T., Marciniuk, D., Denberg, T., Schünemann, H., Wedzicha, W., MacDonald, R., \& Shekelle, P.. (2011). Diagnosis and management of stable chronic obstructive pulmonary disease: a clinical practice guideline update from the American College of Physicians, American College of Chest Physicians, American Thoracic Society, and European Respiratory Society. Annals of internal medicine, 155(3), 179-191

Reema, T., Adepu, R., \& Sabin, T. (2010). Impact of clinical pharmacist intervention on knowledge, attitude and practice (KAP) of patients with chronic obstructive pulmonary disease. International Journal of Pharmacy \&Pharmaceutical Sciences;2(4); 54. 
Restrepo, R. D., Alvarez, M. T., \& Wilkins, R. L. (2008). Medication adherence issues in patients treated for COPD. Int J Chron Obstruct Pulmon Dis, 3(3), 371-384.

Ries, A. L., Bauldoff, G. S., Carlin, B. W., Casaburi, R., Emery, C. F., Mahler, D. A., Make, B., Rochester, C., Zuwallack, R., \& Herrerias, C. (2007). Pulmonary rehabilitation: joint ACCP/AACVPR evidence-based clinical practice guidelines. CHEST Journal, 131(5), 4S-42S.

Salah, M., Hamdi, A., \& Shehata, H. (2013). Improving breathlessness and fatigue in patient with COPD. Journal of American Science, 9(12).

Scott, A. S., Baltzan, M. A., Dajczman, E., \& Wolkove, N. (2011). Patient knowledge in chronic obstructive pulmonary disease: back to basics. COPD: Journal of Chronic Obstructive Pulmonary Disease, 8(5), 375-379.

Serra-Batlles, J., Plaza, V., Badiola, C., \& Morejón, E. (2002). Patient perception and acceptability of multidose dry powder inhalers: a randomized crossover comparison of Diskus/Accuhaler with Turbuhaler. Journal of aerosol medicine, 15(1), 59-64.

Souza, M. L., Meneghini, A. C., Ferraz, E.,Vianna, E. O., \& Borges, M. C. (2009). Knowledge of and technique for using inhalation devices among asthma patients and COPD patients. Jornal Brasileiro de Pneumologia, 35(9), 824-831.

Spencer, P., \& Hanania, N. A. (2013). Optimizing safety of COPD treatments: role of the nurse practitioner. Journal of multidisciplinary healthcare, 6(53-63).

Subba, H. K., \& Subba, R. (2015). Knowledge on self-care among COPD patients attending at Chitwan Medical College Teaching Hospital, Bharatpur. Journal of Chitwan Medical College, 4(3), 34-37.

Thabane, M. \& COPD Working Group.(2012). Smoking cessation for patients with chronic obstructive pulmonary disease (COPD): an evidencebased analysis. Ont Health Technol Assess Ser. ,12(4),1-50.

Walia, G. K., Vellakkal, R., \& Gupta, V. (2016). Chronic Obstructive Pulmonary Disease and its Non-Smoking Risk Factors in India. COPD: Journal of Chronic Obstructive Pulmonary Disease, 13(2), 251-261. 
White, R., Walker, P., Roberts, S., Kalisky, S., \& White, P. (2006). Bristol COPD Knowledge Questionnaire (BCKQ): testing what we teach patients about COPD. Chronic Respiratory Disease, 3(3), 123-131.

World Health Organization (2016a). COPD: Definition. Retrieved April 24, 2014 from: http://www.who.int/respiratory/copd/ definition/en/ .

Zamzam, M. A., Azab, N. Y., El Wahsh, R. A., Ragab, A. Z., \& Allam, E. M. (2012). Quality of life in COPD patients. Egyptian Journal of Chest Diseases and Tuberculosis, 61(4), 281-289.

أثر برنامج تعليمي على المعرفة و الممارسة و الكفاعة الذاتية لمرضى السدة الرئوية المزمنة

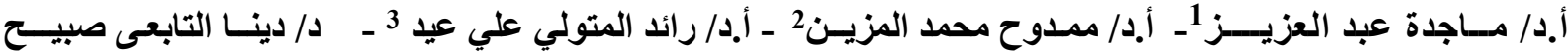
4 ـ أموره عمـر إبراهيـم الموافى 5

أستاذ التهريض الباطني و الجر/حي_ كلبة التهريض- جامعة عين شعس /2 أستاذ الجراحة والأوعية الدموية كلبة الطب - جامعة قناة السوبيس / ßستاذ الصدر- كلية الطب - جامعة الهنصورة / 4مدرس التصريض الباطني و الجراحي ـ كلبة التصريض- جامعة بور سعبد/ 5ماجيستير التصريض الباطني والجراحي ـ كلبة التصريض- جامعة بورسعيد.

\section{الـخـلاصـــة}

يمثل مرض السدة الرئوية المزمنة محور الاهتمام في جميع أنحاء العالم لما يسببه من الأمر اض و الوفيات وارتفاع معدلات الانتشار، وفي مصر يتم التعامل معه كمشكلة صحية عامة أساسية. تهدف هذه الدراسة إلى تقييم اثر برنامج تعليمي علي مستوي المعرفة و الممارسة والكفاءة الذاتية لمرضى السدة الرئوية المزمنة المستقرة. وقد نم استخدام التصميم شبه التجريبي لإجر اء هذه الدراسة وتألفت عينة البحث من جميع المرضى المتاحين (120) الذين يعانون من مرض السدة الرئوية المزمنة المستقرة في العيادة الخارجية لأمراض الجهاز التنفسي في مستشفى جامعة المنصورة. وقد استخدمت اربع أدوات لجمع البيانات: استمارة استبيان و التي شملت بيانات عن خصائص المرضى لئه الثخصية ،التاريخ الحالي ،السابق والتاريخ العائلي للمرض. والتقييم المعرفي و السلوكي وكذللك الكفاءة الذاتية

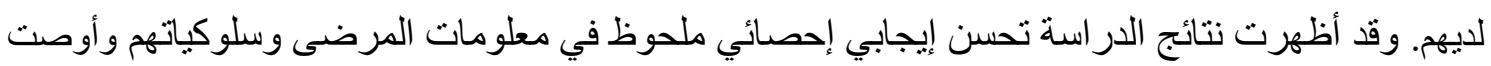
الدر اسة بتقديم برامج تعليمية مستمرة لمرضي السدة الرئوية المزمنة وأسرهم حول مرض السدة الرئوية المزمنة وطرق العلاج و المضاعفات وطرق التخفيف من حدة المضاعفات. الكلـــات الــمرشــةة: مرض السدة الرئوية المزمنة، المعرفة، الممارسة، برنامج تعليمي. 